\title{
Faktor-Faktor yang Berhubungan dengan Perilaku Higienis Remaja saat Menstruasi pada Siswa di SMA Kartika XIV-1 Banda Aceh
}

\author{
Factors Related to Conduct Menstrual Hygiene When Teens on Students SMA \\ Kartika XIV-1 Banda Aceh \\ Zuraida $^{1^{*}}$, Nuzulul Rahmi ${ }^{2}$ \\ ${ }^{1.2}$ Prodi D-III Kebidanan, Universitas Ubudiyah Indonesia, Banda Aceh, Indonesia \\ *Korespondensi Penulis : nuzululrahmi@uui.ac.id
}

\begin{abstract}
Abstrak
Rendahnya perilaku higienis saat menstruasi dapat menimbulkan beberapa penyakit berupa infeksi alat reproduksi seperti vaginitis, trichomoniasis, pedikuloris dan keputihan, hal ini menunjukan banyak nya siswi di SMA Kartika masih kurangnya perilaku higienis remaja saat menstruasi ini disebabkan wawasan pengetahuan dan informasi yang didapatkan remaja masih kurang. Untuk mengetahui faktor-faktor yang berhubungan dengan perilaku higienis remaja saat menstruasi pada siswa di SMA Kartika XIV-1 Banda Aceh. Penelitian ini bersifat analitik dengan pendekatan cross sectional,penelitian ini dilakukan pada tanggal 16 Mei - 03 Juni 2016, populasi yaitu seluruh siswi SMA Kartika XIV-1 sejumlah 51 orang, Tehnik pengambilan sampel dalam penelitian ini dilakukan secara Total Sampling dengan menetapkan semua populasi siswi sebanyak 51 orang sebagai sampel, pengumpulan data dilakukan dengan menggunakan kuesioner. Tehnik analisis data menggunakan Chisquare, dengan Confident Interval (CI) 95\% . Dari hasil uji statistik diperoleh ada hubungan pengetahuan dengan perilaku higienis remaja saat menstruasi $p$ value $(0,041)$, ada hubungan dukungan keluarga dengan perilaku higienis remaja saat menstruasi $\mathrm{p}$ value $(0,001)$, ada hubungan sikap dengan perilaku higienis remaja saat menstruasi $p$ value $(0,006)$. Berdasarkan hasil penelitian ini di dapatkan dari analisis statistik $\mathrm{p}$ value $\leq 0,05$ yaitu ada hubungan pengetahuan, dukungan keluarga dan sikap dengan perilaku higienis remaja saat menstruasi di SMA Kartika XIV-1 Banda Aceh. Diharapkan kepada Kepala sekolah beserta Guru dapat memberikan informasi kepada remaja putri mengenai perilaku higienis remaja saat menstruasi
\end{abstract}

Kata Kunci : Perilaku Higienis, Remaja, Menstruasi

\begin{abstract}
Poor hygiene behaviors during menstruation can cause several diseases such as infectious reproductive organs such as vaginitis, trichomoniasis, pedikuloris and whitish, it shows a lot of his students at SMA Kartika still a lack of hygienic behaviors teens during menstruation is due to the insight and information obtained teenagers still not enough. To determine the factors associated with adolescent menstrual hygiene behaviors in students at SMA Kartika XIV-1 Banda Aceh. This research is an analytic cross sectional study was conducted on 16 May - 03 June 2016, the population of which the entire high school student Kartika XIV-1 number 51, Sampling techniques in this study conducted Total Sampling by setting all student
\end{abstract}


population were 51 people in the sample, the data collection is done by using a questionnaire. Technical analysis of the data using the Chi-square, with Confident Interval (CI) of 95\%. From the statistical test obtained no relation between knowledge with hygienic behaviors adolescent menstrual p value (0.041), there is a relationship of family support with hygienic behaviors adolescent menstrual $p$ value (0.001), there is a relationship attitude with hygienic behaviors teens during menstruation $p$ value (0.006). Based on the results of this study get from statistical analysis $p$ value $\leq 0.05$ is no correlation between knowledge, attitude and support of family and adolescent menstrual hygiene behavior in high school Kartika XIV-1 Banda Aceh. Expected to Head of school and its teachers can provide information to the young women about hygiene behavior of teenagers during menstruation.

Keywords: Hygienic, Youth, Menstrual Behavior

\section{PENDAHULUAN}

Menurut World Health Organization (WHO) (2012), kesehatan reproduksi adalah kesehatan yang sempurna baik fisik, mental, sosial dan lingkungan serta bukan semata-mata terbebas dari penyakit atau kecacatan dalam segala aspek yang berhubungan dengan sistem reproduksi, fungsi serta prosessnya. Departemen Kesehatan (2010), mendefinisikan kesehatan reproduksi adalah keadaan sehat secara menyeluruh serta proses reproduksi. Dengan demikian kesehatan reproduksi bukan hanya kondisi bebas dari penyakit, melainkan bagaimana seseorang dapat memiliki kehidupan seksual yang aman dan memuaskan baik sebelum menikah maupun sesudah menikah. Dengan adanya pengertian kesehatan reproduksi menurut WHO dan Depkes, maka kita harus menjaga segala sesuatu yang berhubungan dengan sistem reproduksi, fungsi serta prosesnya sehingga akan tercipta suatu perilaku yang sehat.

Data SKKRI (Survei Kesehatan Reproduksi Remaja Indonesia) tahun (2009) menyatakan bahwa pengetahuan kesehatan reproduksi remaja masih rendah. Pengetahuan remaja putri tentang tanda akil balik yaitu suara menjadi besar adalah $55 \%$, tumbuh rambut sekitar alat kelamin, ketiak, dada dan kaki 32\%, payudara membesar 36,9\% dan timbul jerawat $13,2 \%$, dan terendah menonjolkan jati diri $0,8 \%$, gairah seks meningkat 2,3\%, tertarik lawan jenis $6,4 \%$, Pengetahuan tentang akil balik wanita mulai haid sebesar 74,9\%

Berdasarkan data penelitian Lisa (2013) tentang kesehatan reproduksi wanita menunjukkan $75 \%$ wanita di dunia pasti menderita keputihan Rendahnya perilaku higienis saat menstruasi dapat menimbulkan beberapa penyakit berupa infeksi alat reproduksi seperti vaginitis, trichomoniasis, pedikuloris dan keputihan.

Menurut Ratna (2014) mengemukakan bahwa perilaku buruk dalam menjaga kebersihan genitalia, seperti mencuci dengan air kotor, memakai pembilas secara berlebihan, 
menggunakan celana yang tidak menyerap keringat, jarang mengganti celana dalam, tak sering mengganti pembalut dapat menjadi pencetus timbulnya infeksi.

Menurut Departemen Kesehatan (2010), kanker yang terjadi pada daerah leher rahim merupakan kanker ke dua paling sering terjadi pada perempuan, dan paling sering disebabkan karena infeksi Human Papilloma Virus (HPV). Data Departemen Kesehatan RI (2010), di Indonesia diperkirakan 52 juta perempuan Indonesia berisiko terkena kanker serviks, sementara $36 \%$ perempuan dari seluruh penderita kanker adalah pasien kanker serviks. Ada 15.000 kasus baru kanker serviks terjadi dengan angka kematian 7.500 kasus per tahun.Kanker serviks merupakan kanker yang paling sering terjadi pada perempuan Indonesia.Tingginya angka kejadian kanker serviks di Indonesia merupakan beban kesehatan, ekonomi dan sosial bagi perempuan di mana pun.

Perilaku higienis remaja pada saat menstruasi masih rendah, diperlihatkan oleh sebuah penelitian Widyantoro (2009) mengenai higienitas menstruasi pada perempuan pengunjung rumah sakit di Subang dan Tangerang mengungkapkan bahwa sebagian besar $(77,5 \%$ di Tangerang dan 68,3 \% di Subang) mempunyai status higienitas menstruasi yang buruk. Dalam hal higienitas individu, masih terdapat responden yang Salah dalam mencuci alat kelaminnya yaitu dari arah belakang ke depan $(20,1 \%$ pada hari biasa dan $19,8 \%$ pada saat menstruasi). Seseorang yang tidak memiliki pengetahuan tentang kesehatan reproduksi yang cukup, akan cenderung mengabaikan kesehatan reproduksinya dan pada akhirnya ia akan melakukan tindakan yang membahayakan bagi dirinya sendiri. Pengetahuan tentang kesehatan reproduksi merupakan faktor penting dalam menentukan perilaku higienis perempuan pada saat menstruasi. Rendahnya pengetahuan tentang kesehatan reproduki akan memungkinkan perempuan tidak berperilaku higienis pada saat menstruasi yang dapat membahayakan kesehatan reproduksinya sendiri (BKKBN, 2012).

Berdasarkan hasil studi pendahuluan yang dilakukan di SMA Kartika XIV-1 Banda Aceh 12 januari 2016 didapatkan informasi jumlah seluruh siswi berjumlah 51 Orang, terdiri dari kelas X sejumlah 18 orang, kelas XI sejumlah 19 orang, kelas XII sejumlah 14 orang. Dengan melakukan wawancara serta membagikan kuesioner kepada 12 orang siswi SMA kartika di dapatkan 5 orang mengetahui kesehatan reproduksi dan perilaku higienis remaja saat menstruasi sedangkan 7 orang lagi tidak mengerti dikarenakan pengetahuan dan informasi yang di dapatkan remaja masih kurang dari perilaku higienis remaja saat mengalami menstruasi. 


\section{METODE PENELITIAN}

Jenis penelitian ini adalah bersifat Analitik dengan desain penelitian cross sectional, dimana variabel independen dan variabel dependen diteliti secara bersamaan pada saat penelitian dilakukan.Penelitian dilakukan bertujuan untuk mengetahui Faktor-Faktor yang berhubungan dengan Perilaku Higienis Remaja saat Menstruasi pada siswi di SMA Kartika XIV-1 Banda Aceh. Penelitian ini dilaksanakan di SMA Kartika X1V-1 Banda Aceh. Penelitian ini telah dilaksanakan pada tanggal 20 Mei - 03 Juni 2016. Dalam penelitian ini adalah keseluruhan objek penelitian yang diteliti, dimana penelitian yang diteliti dalam penelitian ini adalah seluruh siswi SMA Kartika X1V-1 sejumlah 51 orang. Sampel dalam penelitian ini dilakukan secara total sampling yaitu dengan cara menetapkan semua populasi siswi sebanyak 51 orang sebagai keseluruhan sampel yang akan diteliti.

\section{HASIL PENELITIAN}

Tabel 1. Distribusi Frekuensi Perilaku Higienis Remaja Saat Menstruasi pada Siswa di SMA Kartika XIV-1 Banda Aceh

\begin{tabular}{ccccc}
\hline No & & Perilaku Higienis & f & \% \\
\hline 1 & Positif & & 30 & 58,8 \\
2 & Negatif & & 21 & 41,2 \\
\hline & & Total & $\mathbf{5 1}$ & $\mathbf{1 0 0}$ \\
\hline
\end{tabular}

Berdasarkan Tabel 1 dapat menunjukan bahwa dari 51 responden dengan Perilaku higienis yang Positif yaitu sebanyak 30 responden $(58,8 \%)$ sedangkan perilaku higienis yang negatif yaitu sebanyak 21 responden $(41,2 \%)$.

Tabel 2. Distribusi Frekuensi Pengetahuan pada Responden di SMA Kartika XIV-1 Banda Aceh

\begin{tabular}{ccccc}
\hline No & & Pengetahuan & f & \% \\
\hline 1 & Baik & & 22 & 43,1 \\
2 & Kurang baik & & 29 & 56,9 \\
\hline & & Total & $\mathbf{5 1}$ & $\mathbf{1 0 0}$ \\
\hline
\end{tabular}

Berdasarkan tabel 2 dapat menunjukkan bahwa dari 51 responden yang berpengetahuan kurang baik yaitu sebanyak 29 responden $(56,9 \%)$, sedangkan remaja yang berpengetahuan baik sebanyak 22 responden $(43,1 \%)$. 
Tabel 3. Distribusi Frekuensi Dukungan Keluarga pada Respondendi SMA Kartika XIV-1 Banda Aceh

\begin{tabular}{|c|c|c|c|}
\hline No & Dukungan keluarga & $\mathrm{f}$ & $\%$ \\
\hline 1 & Mendukung & 28 & 54,9 \\
\hline 2 & Tidak Mendukung & 23 & 45,1 \\
\hline & Total & 51 & 100 \\
\hline
\end{tabular}

Berdasarkan tabel 3 dapat menunjukkan bahwa dari 51 responden dengan Keluarga yang Mendukung yaitu sebanyak 28 responden (54,9\%), sedangkan remaja dengan keluarga yang tidak mendukung sebanyak 23 responden $(45,1 \%)$.

Tabel 4. Distribusi Frekuensi Sikap pada Responden Di SMA Kartika XIV-1 Banda Aceh

\begin{tabular}{clccc}
\hline No & & Sikap & f & \% \\
\hline 1 & Positif & & 20 & 39,2 \\
2 & Negatif & & 31 & 60,8 \\
\hline & & Total & $\mathbf{5 1}$ & $\mathbf{1 0 0}$
\end{tabular}

Berdasarkan tabel 4 dapat menunjukkan bahwa dari 51 responden dengan remaja yang memiliki Sikap Negatif yaitu sebanyak 31 responden $(60,8 \%)$, sedangkan remaja yang memiliki sikap positif sebanyak 20 responden $(39,2 \%)$.

Tabel 5. Hubungan Pengetahuan dengan Perilaku Higienis Remaja Saat Menstruasi pada Siswa Di SMA Kartika XIV-1 Banda Aceh

\begin{tabular}{|c|c|c|c|c|c|c|c|c|}
\hline \multirow{3}{*}{ No } & \multirow{3}{*}{ Pengetahuan } & \multicolumn{4}{|c|}{$\begin{array}{c}\text { Perilaku Higienis Remaja saat } \\
\text { Menstruasi }\end{array}$} & \multirow{2}{*}{\multicolumn{2}{|c|}{ Total }} & \multirow[t]{3}{*}{ P-value } \\
\hline & & \multicolumn{2}{|c|}{ Positif } & \multicolumn{2}{|c|}{ Negatif } & & & \\
\hline & & $\mathbf{F}$ & $\%$ & $\mathbf{f}$ & $\%$ & $\mathbf{f}$ & $\%$ & \\
\hline 1 & Baik & 17 & 77,3 & 5 & 22,7 & 22 & 100 & \\
\hline \multirow[t]{2}{*}{2} & Kurang Baik & 13 & 44,8 & 16 & 55,2 & 29 & 100 & 0,041 \\
\hline & & 30 & & 21 & & 51 & & \\
\hline
\end{tabular}


Berdasarkan tabel 5 dapat dilihat bahwa dari 22 responden dengan tingkat pengetahuan yang baik terhadap perilaku higienis remaja yang positif saat menstruasi sebanyak 77,3\% sedangkan dari 29 responden dengan tingkat pengetahuan remaja yang kurang baik terhadap perilaku higienis remaja yang positif saat menstruasi sebanyak 44,8\%.

Hasil analisis statistik menggunakan uji chi-square didapatkan $p$-value $=0,041$. Sehingga dapat disimpulkan bahwa $\mathrm{p}<0,05$ yang artinya Ha diterima atau terdapat hubungan pengetahuan dengan perilaku higienis remaja saat menstruasi.

Tabel 6. Hubungan Dukungan Keluarga Dengan Perilaku Higienis Remaja Saat Menstruasi Pada Siswa Di SMA Kartika XIV-1 Banda Aceh

\begin{tabular}{|c|c|c|c|c|c|c|c|c|}
\hline \multirow{3}{*}{ No } & \multirow{3}{*}{$\begin{array}{l}\text { Dukungan } \\
\text { Keluarga }\end{array}$} & \multicolumn{4}{|c|}{$\begin{array}{c}\text { Perilaku Higienis Remaja saat } \\
\text { Menstruasi }\end{array}$} & \multirow{2}{*}{\multicolumn{2}{|c|}{ Total }} & \multirow[t]{3}{*}{ P-value } \\
\hline & & \multicolumn{2}{|c|}{ Positif } & \multicolumn{2}{|c|}{ Negatif } & & & \\
\hline & & $\mathbf{F}$ & $\%$ & $\mathbf{f}$ & $\%$ & $\mathbf{F}$ & $\%$ & \\
\hline 1 & Mendukung & 23 & 82,1 & 5 & 17,9 & 28 & 100 & \\
\hline \multirow[t]{2}{*}{2} & $\begin{array}{l}\text { Tidak } \\
\text { Mendukung }\end{array}$ & 7 & 30,4 & 16 & 69,6 & 23 & 100 & 0,001 \\
\hline & & 30 & & 21 & & 51 & & \\
\hline
\end{tabular}

Berdasarkan tabel 6 dapat dilihat bahwa dari 28 responden dengan remaja yang keluarga mendukung terhadap perilaku higienis remaja yang positif saat menstruasi sebanyak $82,1 \%$, sedangkan dari 23 responden remaja yang keluarganya tidak mendukung terhadap perilaku higienis remaja yang positif saat menstruasi sebanyak 30,4\% .

Hasil analisis statistik menggunakan uji chi-square didapatkan p-value $=0,001$. Sehingga dapat disimpulkan bahwa $\mathrm{p}<0,05$ yang artinya Ha diterima atau terdapat hubungan dukungan keluarga dengan perilaku higienis remaja saat menstruasi.

Tabel 7. Hubungan Sikap Dengan Perilaku Higienis Remaja Saat Menstruasi pada Siswa di SMA Kartika XIV-1 Banda Aceh

\begin{tabular}{|c|c|c|c|c|c|c|c|c|}
\hline \multirow{3}{*}{ No } & \multirow{3}{*}{ Sikap } & \multicolumn{4}{|c|}{$\begin{array}{c}\text { Perilaku Higienis Remaja saat } \\
\text { Menstruasi }\end{array}$} & \multirow{2}{*}{\multicolumn{2}{|c|}{ Total }} & \multirow{3}{*}{$\begin{array}{c}\text { P- } \\
\text { value }\end{array}$} \\
\hline & & \multicolumn{2}{|c|}{ Positif } & \multicolumn{2}{|c|}{ Negatif } & & & \\
\hline & & $\mathbf{F}$ & $\%$ & f & $\%$ & f & $\%$ & \\
\hline 1 & Positif & 17 & 85 & 3 & 15 & 20 & 100 & \\
\hline 2 & Negatif & 13 & 41,9 & 18 & 58,1 & 31 & 100 & 0,006 \\
\hline & & 30 & & 21 & & 51 & & \\
\hline
\end{tabular}


Berdasarkan tabel 7 dapat dilihat bahwa dari 20 responden sikap remaja yang positif terhadap perilaku higienis remaja ssaat menstruasi sebanyak 85\%, sedangkan dari 31 responden sikap remaja yang negative terhadap perilaku higienis remaja saat menstruasi sebanyak $41,9 \%$.

Hasil analisis statistik menggunakan uji chi-square didapatkan p-value $=0,006$. Sehingga dapat disimpulkan bahwa $\mathrm{p}<0,05$ yang artinya Ha diterima atau terdapat Hubungan Sikap Dengan Perilaku Higienis Remaja Saat Menstruasi.

\section{Pembahasan}

1. Hubungan Pengetahuan dengan Perilaku Higienis Remaja Wanita Saat Menstruasi

Berdasarkan hasil penelitian yang telah dilakukan oleh peneliti menunjukkan bahwa dari 22 responden dengan tingkat pengetahuan yang baik terhadap perilaku higienis remaja yang positif saat menstruasi sebanyak 77,3\% sedangkan dari 29 responden dengan tingkat pengetahuan remaja yang kurang baik terhadap perilaku higienis remaja yang positif saat menstruasi sebanyak 44,8\%. Maka dapat disimpulkan bahwa remaja dengan Tingkat pengetahuan yang kurang baik dengan perilaku higienis remaja yang negatif saat menstruasi lebih banyak dibandingkan dengan remaja yang tingkat pengetahuannya baik saat perilaku higienis remaja saat menstruasi.

Hasil analisis statistik menggunakan uji chi-square didapatkan p-value $=0,041$. Sehingga dapat disimpulkan bahwa $\mathrm{p}<0,05$ yang artinya Ha diterima atau terdapat Hubungan Pengetahuan Dengan Perilaku Higienis Remaja Saat Menstruasi.

Menurut Penelitian Wahyulisasni (2010) yang dilakukan di SMP Pembangunan Universitas Negeri Padang (UNP) menunjukkan tingkat pengetahuan siswi tentang menstruasi. Siswi dengan pengetahuan tinggi tentang menstruasi sebanyak 43,4\%, siswi dengan pengetahuan sedang sebanyak $51,3 \%$, dan sisa dengan pengetahuan rendah sebanyak 5,3\%.Setelah dilakukan uji statistik dengan menggunakan chi-square maka diperoleh nilai $p$-value $0,000(<0,05)$, dengan demikian dapat ditarik kesimpulan bahwa ada hubungan Pengetahuan dengan Perilaku higienis Remaja saat menstruasi.

Menurut Penelitian Nurma (2011) yang dilakukan di SMA 2 Semarang menunjukkan tingkat pengetahuan siswi tentang menstruasi. dengan pengetahuan tinggi saat menstruasi sebanyak 66,6\%, siswi dengan pengetahuan sedang sebanyak 29,4\%, dan sisa dengan pengetahuan rendah sebanyak $100 \%$.Setelah dilakukan uji statistik dengan 
menggunakan chi-square maka diperoleh nilai p-value0,003 $(<0,05)$, dengan demikian dapat ditarik kesimpulan bahwa ada hubungan Pengetahuan dengan Perilaku higienis Remaja saat menstruasi.

Menurut Penelitian Sri Haryati (2013) menunjukkan tingkat pengetahuan siswi saat menstruasi.dengan pengetahuan yang baik saat menstruasi sebanyak 66,5\% siswi dengan pengetahuan kurang sebanyak 59,4 \%, Setelah dilakukan uji statistik dengan menggunakan chi-square maka diperoleh nilai p-value $0,001(<0,05)$, dengan demikian dapat ditarik kesimpulan bahwa ada hubungan Pengetahuan dengan Perilaku higienis Remaja saat menstruasi.

Pengetahuan adalah merupakan hasil dari tahu dan ini terjadi setelah orang melakukan Pengindaran terhadap objek tertentu. Penginderaan terhadap objek terjadi melalui panca indra manusia, yakni; penglihatan, pendengaran, penciuman, rasa, dan raba. Sebagian besar pengetahuan manusia diperoleh melalui mata dan telinga (Notoatmodjo, 2007 dalam Sari 2012).

Pengetahuan tentang kesehatan reproduksi merupakan faktor penting dalam menentukan perilaku higienis perempuan pada saat menstruasi. Rendahnya pengetahuan tentang kesehatan reproduksi akan memungkinkan perempuan tidak berperilaku higienis pada saat menstruasi yang dapat membahayakan kesehatan reproduksinya sendiri (BKKBN, 2012).

Menurut Asumsi peneliti, menyatakan bahwa hubungan pengetahuan dengan perilaku higienis remaja saat menstruasi di SMA Kartika XIV-1 Banda Aceh banyak dijumpai tingkat pengetahuan yang kurang baik terhadap perilaku higienis remaja saat menstruasi sebanyak 44,8\%, hal ini disebabkan karena informasi yang di dapatkan remaja masih kurang, sehingga seseorang yang memiliki pengetahuan baik akan semakin positif pula tentang Perilaku higienis Remaja saat menstruasi, dan sebaliknya jika Remaja memiliki pengetahuan kurang maka akan berdampak semakin negatif terhadap Perilaku Higienis Remaja saat Menstruasi, karena pengetahuan sangat berpengaruh terhadap remaja yang mengalami perilaku higienis remaja saat menstruasi

2. Hubungan Dukungan Keluarga Dengan Perilaku Higienis Remaja Wanita Saat Menstruasi

Berdasarkan hasil penelitian yang telah dilakukan oleh peneliti menunjukkan bahwa dari 28 responden dengan remaja yang keluarga mendukung terhadap perilaku 
higienis remaja yang positif saat menstruasi sebanyak 82,1\%, sedangkan dari 23 responden remaja yang keluarganya tidak mendukung terhadap perilaku higienis remaja yang positif saat menstruasi sebanyak 30,4\% .Maka dapat disimpulkan bahwa Remaja dengan Keluarga yang mendukung lebih banyak mengalami perilaku higienis remaja saat menstruasi yang positif dibandingkan Remaja dengan keluarga yang tidak mendukung.

Hasil analisis statistik menggunakan uji chi-square didapatkan $\quad$-value $=0,001$. Sehingga dapat disimpulkan bahwa $\mathrm{p}<0,05$ yang artinya Ha diterima atau terdapat Hubungan Dukungan Keluarga Dengan Perilaku Higienis Remaja Saat Menstruasi.

Berdasarkan hasil penelitian Rina (2013) menunjukkan bahwa dari 33 responden, yangmendapat dukungan keluarga sebanyak 31 orang $(93,9 \%)$ dengan perilaku Higienis remaja saat menstruasi yang mendukung Sedangkan dari 16 responden yang tidak mendapat dukungan keluarga sebanyak 15 orang $(93,8 \%)$ perilaku higienis remaja saat menstruasi tidak Mendukung Berdasarkan Uji Chi-Square di peroleh nilai $\mathrm{P}=0,000$ jika $\mathrm{P}-$ Value $\leq \alpha=0,05$. dengan demikian dapat ditarik kesimpulan bahwa ada hubungan antara Dukungan keluarga dengan perilaku higienis Remaja saat menstruasi.

Berdasarkan hasil penelitian Ratih (2010) menunjukkan bahwa dengan dukungan keluarga yang mendukung sebanyak 30 orang $(83,9 \%)$ dengan perilaku Higienis remaja saat menstruasi Sedangkan dari 16 responden yang tidak mendapat dukungan keluarga sebanyak 13 orang $(76,8 \%)$ perilaku higienis remaja saat menstruasi tidak Mendukung Berdasarkan Uji Chi-Square di peroleh nilai $\mathrm{P}=0,000$ jika $\mathrm{P}-$ Value $\leq \alpha=0,05$. dengan demikian dapat ditarik kesimpulan bahwa ada hubungan antara Dukungan keluarga dengan perilaku higienis Remaja saat menstruasi.

Berdasarkan hasil penelitian yang dilakukan oleh Santi (2012) diperoleh bahwa dari 90 responden,70,5\% Remaja dengan dukungan keluarga yang mendukung dan 59,8\% remaja dengan dukungan keluarga yang tidak mendukung terhadap perilaku higienis remaja saat menstruasi. Dari Hasil analisa statistik dengan menggunakan uji chi square menunjukkan ada hubungan antara dukungan keluarga dengan perilaku higienis remaja saat menstruasi dengan nilai $\mathrm{p}$ value $0,000(\mathrm{P}<0,05)$ dengan demikian dapat ditarik kesimpulan bahwa ada hubungan antara Dukungan keluarga dengan perilaku higienis Remaja saat menstruasi.

Dukungan keluarga didefinisikan Zainudin (2010) yaitu informasi verbal, sasaran, bantuan yang nyata atau tingkah laku yang diberikan oleh orang-orang yang akrab dengan 
subjek didalam lingkungan sosialnya atau yang berupa kehadiran dan hal yang dapat memberikan keuntungan emosional atau pengaruh pada tingkah laku penerimaannya. Dalam hal ini orang yang merasa memperoleh dukungan sosial, secara emosional merasa lega diperhatikan, mendapat saran atau kesan yang menyenangkan pada dirinya.

Menurut Ratih (2008) dukungan keluarga pada Remaja dalam perilaku higienis remaja saat menstruasi adalah sebagai adanya informasi, perhatian, penghargaan atau menolong dengan sikap menerima kondisinya, dukungan keluarga tersebut diperoleh dari individu maupun kelompok.

Menurut Asumsi peneliti menyatakan bahwa hubungan dukungan keluarga dengan perilaku higienis remaja saat menstruasi di SMA Kartika XIV-1 Banda Aceh banyak dijumpai remaja dengan keluarga yang mendukung terhadap perilaku higienis yang positif saat menstruasi sebanyak 82,1\%, hal ini disebabkan remaja dengan keluarga yang mendukung memberikan support, dukungan materi untuk membeli fasilitas alat pembersih yang dapat langsung dipakai seperti pembalut yang tidak menggunakan kain dan sebagian dari remaja yang keluarga tidak mendukung masih membiasakan remaja dengan alat pembalut tradisional menggunakan kain saat menstruasi, dukungan keluarga sangat berpengaruh terhadap perilaku Higienis Remaja saat menstruasi, karena dukungan keluarga dapat berupa dukungan emosional, materi dan informasi dimana remaja membutuhakan semua hal-hal tersebut. Sehingga semakin keluarga mendukung maka semakin positif pula perilaku higienis remaja saat menstruasi dan sebaliknya jika keluarga tidak mendukung maka semakin negatif pula perilaku Higienis remaja saat menstruasi

3. Hubungan Sikap Dengan Perilaku Higienis Remaja Wanita Saat Menstruasi

Berdasarkan hasil penelitian yang telah dilakukan oleh peneliti menunjukkan bahwa dari 20 responden sikap remaja yang positif terhadap perilaku higienis remaja ssaat menstruasi sebanyak $85 \%$, sedangkan dari 31 responden sikap remaja yang negative terhadap perilaku higienis remaja saat menstruasi sebanyak 41,9\%. Maka dapat disimpulkan bahwa remaja yang sikap Negatif lebih banyak mengalami perilaku Higienis Remaja saat menstruasi dibandingkan siswa yang bersikap positif.

Hasil analisis statistik menggunakan uji chi-square didapatkan p-value $=0,006$. Sehingga dapat disimpulkan bahwa $\mathrm{p}<0,05$ yang artinya Ha diterima atau terdapat Hubungan Sikap Dengan Perilaku Higienis Remaja Saat Menstruasi. 
Penelitian sri raharyu (2008) yang dilakukan di SMA bukit tinggi menunjukkan sikap siswi tentang menstruasi. Siswi dengan sikap yang tinggi mengetahui tentang menstruasi sebanyak 42,4\%, siswi dengan sikap sedang sebanyak 51,3\%, dan sisa dengan sikap rendah sebanyak 5,3\%. Responden mempunyai sikap mendukung terhadap perilaku kebersihan saat menstruasi, ini terlihat dari hasil uji chi square, dengan analisis bivariat mendapatkan nilai $\mathrm{p}=0,002$, artinya dengan nilai $\alpha=0,05$ maka nilai $\mathrm{p}$ tersebut $<$ dari $\alpha$ sehingga dapat disimpulkan bahwa sikap responden mempunyai hubungan yang signifikan terhadap perilaku kebersihan pada saat menstruasi, dengan nilai OR 3,491 berarti bahwa siswi dengan sikap mendukung akan memiliki kemungkinan 3,491 kali lebih besar melakukan perilaku kebersihan pada saat menstruasi yang baik dibandingkan dengan sikap kurang mendukung.

Penelitian wahyuni (2010) dari 46 responden bersikap positif yang mengalami perilaku higienis remaja saat menstruasi sebanyak 33 orang $(71,7 \%)$ dan dari 24 responden yang bersikap negatif yang mengalami perilaku higienis remaja saat menstruasi sebanyak 11 orang $(42,3 \%)$. Hasil analisis statistic menunjukan bahwa ada hubungan antara sikap dengan perilaku higienis remaja saat menstruasi dengan P-Value =0,006.

Penelitian Ningsih (2014) dari 60 responden bersikap positif yang mengalami perilaku higienis remaja saat menstruasi sebanyak 32 orang $(69,7 \%)$ dan dari 28 responden yang bersikap negatif yang mengalami perilaku higienis remaja saat menstruasi sebanyak 15 orang $(48,3 \%)$. Hasil analisis statistik menunjukan bahwa ada hubungan antara sikap dengan perilaku higienis remaja saat menstruasi dengan P-Value $=0,000$.

Sikap adalah merupakan kesiapan atau kesediaan untuk bertindak, dan bukan merupakan pelaksanaan motif tertentu. Dalam kata lain fungsi sikap belum merupakan tindakan (reaksi terbuka) atau aktifitas, akan tetapi merupakan predisposisi perilaku (tindakan), atau reaksi tertutup (Notoatmodjo, 2010).

Menurut Notoatmodjo (2010) sikap itu terdiri dari 3 komponen pokok, yaitu : (1) Kepercayaan atau keyakinan, ide, dan konsep terhadap objek, artinya bagaimana keyakinan, pendapat atau pemikiran Remaja terhadap perilaku higienis remaja saat menstruasi (2) Kehidupan emosional atau evaluasi orang terhadap objek, artinya bagaimana penilaian (terkandung didalam faktor emosi) Remaja terhadap perilaku higienis remaja saat menstruasi, (3) Kecenderungan untuk bertindak (tend to behave), artinya sikap adalah merupakan komponen yang mendahului tindakan atau perilaku 
terbuka. misalnya sikap Remaja untuk bertindak atau berperilaku terhadap perilaku higienis remaja saat menstruasi.

Menurut Asumsi peneliti, menyatakan bahwa hubungan sikap dengan perilaku higienis remaja saat menstruasi di SMA Kartika XIV-1 Banda Aceh banyak dijumpai remaja dengan sikap yang negatif terhadap perilaku higienis remaja saat menstruasi yaitu sebanyak 58,1\%, hal ini disebabkan sikap remaja dalam memperhatikan kebiasaan mengganti pembalut masih kurang, sikap yang menghiraukan hal sesuatu menjadi spele sehingga mengakibatkan remaja mengalami gatal di area vulva saat menstruasi, lecet dan sebagainya, karena sikap merupakan kesiapan seseorang dalam bertindak sehingga akan sangat berpengaruh terhadap tindakan yang dilakukan oleh seseorang. Semakin positif sikap seseorang maka akan semakin positif pula pandangan seseorang tentang perilaku higienis remaja saat menstruasi.

\section{KESIMPULAN}

Berdasarkan hasil penelitian yang telah dilakukan maka peneliti dapat mengumpulkan hasil dari penelitian sebagai berikut :

1. Terdapat hubungan Pengetahuan dengan Perilaku Higienis Remaja Saat Menstruasi di SMA Kartika XIV-1 Banda Aceh dengan $\mathrm{p}$ value $=0,041$.

2. Terdapat hubungan Dukungan Keluarga dengan Perilaku Higienis Remaja Saat Menstruasi di SMA Kartika XIV-1 Banda Aceh dengan $\mathrm{p}$ value $=0,001$

3. Terdapat hubungan Sikap dengan Perilaku Higienis Remaja Saat Menstruasi di SMA Kartika XIV-1 Banda Aceh dengan p value $=0,006$

\section{SARAN}

Diharapkan hasil penelitian ini dapat memberikan informasi dan dapat digunakan sebagai bahan pertimbangan dan sekaligus sebagai bahan perencanaan bagi tenaga kesehatan dalam memberikan informasi kepada remaja. Bagi Masyarakat khususnya orang tua remaja putri dapat mengetahui serta memahami tentang perilaku hygiene pada saat menstruasi dan untuk menambah wawasan serta informasi. 


\section{DAFTAR PUSTAKA}

Azwar. (2009).Sikap Manusia Teori Dan Pengukurannya.Yogyakarta:Pustaka Pelajar

Ahma d,Dahro.(2012).pengetahuan Remaja Terhadap kesehatan Reproduksi.skripsi (Jakarta : FKM UI,2012 : 18).

BKKBN.(2012).Buku pedoman perilaku Higienis saat Menstruasi. Edisi kedua,Jakarta: ECG.

Depkes RI,(2004) . Higienis Remaja.Departemen Kesehatan Republik Indonesia : Jakarta.

Indonesia, Jakarta.

, (2010). Problem Kesehatan Reproduksi.departemen Kesehatan Republik

Data SKRRI.(2009).Presentasi Pengetahuan Remaja Terhadap Kesehatan Reproduksi.http://www.academia.go.id( dikutip 3 Maret 2016)

Sulistyawati. (2013). Angka perkembangan penduduk Indonesia,http://perkembangan di Indonesia.ac.id dikutip tanggal 28 juli 2016

Suryati, B, Jurnal Health Quality Volume 3 no 1 November 2012, Perilaku kebersihan remaja saat menstruasi (Jakarta, 2012).

Sinthia.(2013).15 jurnal_65 Hasil penelitian.http://jurnal perilaku higienis saat menstruasi.ac.id (dikutip 5 juni 2014) 